\title{
Protection of Human Rights Defenders and Whistleblowers under Human Rights Law
}

\author{
Veronika Bílková
}

In October 2019, the European Union (EU) adopted a new directive on the protection of persons who report breaches of Union law, also known as the Whistleblower Protection Directive. ${ }^{1}$ The Directive, in force since December 2019, is the first international legal instrument reflecting the increased vulnerability of those who expose certain illegal or unethical activities within a private or public organisation. This increased vulnerability is shared by other groups of persons acting in general interest, especially human rights defenders. Individuals who seek to actively defend or promote human rights might have their own human rights threatened or violated. In acknowledgement of this fact, the UN General Assembly adopted, in 1998, the UN Declaration on Human Rights Defenders. ${ }^{2}$ These normative developments suggest that international law is neither indifferent to nor ignorant of the special needs of those who risk their well-being and sometimes also their life for the common good. This chapter identifies the challenges that human rights defenders and whistleblowers face and scrutinises how international law and regional human rights law in Europe respond to these challenges.

The chapter consists of three parts. The first part introduces the concepts of human rights defenders and of whistleblowers. It provides a definition of the two concepts and makes a comparison between them (A.). The second part explores how the increased vulnerability of human rights defenders and whistleblowers manifests itself both in their private life and in the public space (B.). The third part discusses how international law has responded to this increased vulnerability of human rights defenders and whistleblowers and identifies some gaps in these responses (C.). The chapter relies on the European Convention on Human Rights

1 Directive (EU) 2019/1937 of the European Parliament and of the Council of 23 October 2019 on the protection of persons who report breaches of Union law.

2 UN General Assembly, Declaration on the Right and Responsibility of Individuals, Groups and Organs of Society to Promote and Protect Universally Recognized Human Rights and Fundamental Freedoms, 8 March 1999, UN Doc. A/RES/53/144. 
(ECHR) and the case-law of the European Court of Human Rights (ECtHR). It also draws on other human rights instruments applicable in Europe, especially those adopted within the United Nations (UN), the Council of Europe (CoE) and the European Union (EU).

\section{A. Who are Human Rights Defenders and Whistleblowers?}

This part introduces the concepts and provides definitions of human rights defenders (I.) and of whistleblowers (II.). It casts light on the origins of the two concepts and discusses whether and if so, when and in what context, they have become part of international law. It also draws a comparison between the two concepts (III.).

\section{Who are Human Rights Defenders?}

The term 'human rights defender' is not yet a legal term of art. It does not appear in virtually any treaty or other binding international instrument. ${ }^{3}$ Even the so-called UN Declaration on Human Rights Defenders, however surprising it may seem, fails to use this term explicitly in its official title or its text. Notwithstanding that, references to 'human rights defenders' appear not only in materials relating to the UN Declaration, ${ }^{4}$ but also in reports $^{5}$ and non-binding guidelines issued by international organisations ${ }^{6}$

3 One exception to this rule is the 2018 Regional Agreement on Access to Information, Public Participation and Justice in Environmental Matters in Latin America and the Caribbean, which refers explicitly to human rights defenders in environmental matters (Article 9). The Agreement provides no definition of the term.

4 See Wille and Spannagel, 'The history of the UN Declaration on Human Rights Defenders: its genesis, drafting and adoption', Universal Rights Group Blog, 11 March 2019, https://www.universal-rights.org/blog/the-un-declaration-on-human-ri ghts-defenders-its-history-and-drafting-process/.

5 Inter-American Commission on Human Rights, Criminalization of the Work of Human Rights Defenders, 31 December 2015, OEA/Ser.L/V/II. Doc. 49/15; CoE Parliamentary Assembly, Protecting human rights defenders in Council of Europe member States, Report, 6 June 2018, Doc. 14567.

6 See CoE Committee of Ministers, Declaration on Council of Europe action to improve the protection of human rights defenders and promote their activities, 6 February 2008; Council of the EU, Ensuring Protection - European Union Guidelines on Human Rights Defenders, 1 December 2008, 16332/1/08. 
as well as in scholarly literature. ${ }^{7}$ In the past, several alternative terms were regularly used, such as human rights activists, human rights workers, human rights professionals, human rights monitors or (human rights) dissidents. While these terms have not completely disappeared from the vocabulary, they have become much less common over the past decades, while the term human rights defenders has prevailed. Some of these alternative terms, moreover, are only used in a specific context (e.g. the term dissident is usually reserved for those criticising and opposing political practices embraced by totalitarian or authoritarian regimes).

Due to its absence from international instruments, the term 'human rights defenders' has not received any formal legal definition so far. ${ }^{8}$ Most international institutions, legal scholars and defenders themselves take, however, the official title and Article 1 of the UN Declaration as the primary sources of inspiration. The title refers to individuals, groups and organs of society /who/ promote and protect universally recognized human rights and fundamental freedoms'. Article 1 indicates that '[e]veryone has the right, individually and in association with others, to promote and to strive for the protection and realization of human rights and fundamental freedoms at the national and international levels.'

Most policy documents and non-binding guidelines on human rights defenders either quote one of these definitions directly or provide a paraphrase thereof. The UN Office of the High Commissioner for Human Rights (UN OHCHR) in its 2004 Fact Sheet on Human Rights Defenders suggests that "human rights defender" is a term used to describe people who, individually or with others, act to promote or protect human rights. 9 For the EU, human rights defenders are 'those individuals, groups and organs of society that promote and protect universally recognised human rights and fundamental freedoms'. ${ }^{10}$ The OSCE quotes the UN Declaration in stating that 'human rights defenders act "individually or in association with others, to promote and to strive for the protection and realization of

7 See Bennett et al., 'Critical perspectives on the security and protection of human rights defenders' (2015) 19(7) IJHR, 883; Donders, 'Defending the Human Rights Defenders' (2016) 34(4) NQHR 282; Landman, 'Holding the Line: Human Rights Defenders in the Age of Terror' (2016) 8(2) BJPIR 123.

8 See Koula, 'The UN Definition of Human Rights Defenders: Alternative Interpretative Approaches' (2019) 5(1) QMHRR 1.

9 UN OHCHR, Human Rights Defenders: Protecting the Right to Defend Human Rights. Fact Sheet No. 29 (2004), 2.

10 Council of the EU, Ensuring Protection - European Union Guidelines on Human Rights Defenders, 1 December 2008, 16332/1/08, para. 3. 
human rights and fundamental freedoms"' and adds that this can be done 'at the local, national, regional and international levels'. ${ }^{11}$ The Parliamentary Assembly of the Council of Europe describes human rights defenders as "those who work for the rights of others" - individuals or groups who act, in a peaceful and legal way, to promote and protect human rights'. ${ }^{12}$

Despite certain differences, all the definitions of human rights defenders share the same elements. These elements are three-fold. The first one relates to the actors, i.e. who human rights defenders are. They are individuals, groups of individuals or organised entities - non-governmental organisations and, in the broadest understanding, even State bodies and inter-governmental organisations. ${ }^{13}$ A political dissident in China, the French branch of Amnesty International, the national ombuds-institution in Peru and the UN OHCHR could all qualify as human rights defenders. Thus, the term is not reserved to collective entities only and it is probably not reserved to those acting outside the official structures either. Equating human rights defenders with NGOs, as is sometimes the case, would therefore be incorrect.

The second element pertains to the activity, i.e. what human rights defenders do. Generally, they act to promote and protect human rights. More specifically, they may engage in various activities, especially those listed by the UN OHCHR in its Fact Sheet. Those activities encompass collecting and disseminating information on human rights violations, supporting victims of such violations, engaging in action to secure accountability and to end impunity, supporting better governance and government policy, contributing to the implementation of human rights treaties, and taking active part in human rights education and training. ${ }^{14}$ Which field of human rights human rights defenders work in and whether they do so in their professional or private capacity is irrelevant for their status.

The third element concerns the mode of operation, i.e. how human rights defenders act. The UN OHCHR stresses that 'the actions taken

11 OSCE, Guidelines on the Protection of Human Rights Defenders (2014), 1.

12 CoE Parliamentary Assembly, Protecting human rights defenders in Council of Europe member States, 26 June 2018, Resolution 2225 (2018), para. 1.

13 For a broad definition of human rights defenders, encompassing 'certain civil servants, members of NHRIs, [...] and staff of the United Nations', see UN Economic and Social Council, Promotion and Protection of Human Rights. Human Rights Defenders. Report submitted by the Special Representative of the Secretary-General on human rights defenders, Hina Jilani, 23 January 2006, UN Doc. E/CN.4/2006/95, para. 29.

14 UN OHCHR, Human Rights Defenders: Protecting the Right to Defend Human Rights. Fact Sheet No. 29 (2004), 3 ff. 
by human rights defenders must be peaceful'. ${ }^{15}$ Individuals and groups resorting to violent means thus remain outside the scope of the concept. Human rights defenders should also believe in human rights and accept the universality of these rights. Apart from that, they are not subject to any special requirements or qualifications. Thus, to quote again from the UN OHCHR Fact Sheet, 'human rights defenders can be any person or group of persons working to promote human rights [...]. Defenders can be of any gender, of varying ages, from any part of the world and from all sorts of professional or other backgrounds'. ${ }^{16}$ This implies that 'we can all be defenders of human rights if we choose to be'. ${ }^{17}$

\section{Who are Whistleblowers?}

The term 'whistleblower' dates back to the $19^{\text {th }}$ century, when it was coined in the US to describe law enforcement officials who used a whistle to alert fellow officials or the public about an emergency situation. In the 1970s-1980s, it started to be used to denote individuals who informed about certain negative phenomena in society. ${ }^{18}$ The term entered the legal vocabulary, first at the national level, at the turn of the millennium. In 2019, the Whistleblower Protection Directive, adopted within the EU, became the first - and so far the only - international legally binding instrument dealing specifically with persons falling within this category. ${ }^{19}$ The Directive does not use the term 'whistleblowers' in its title but invokes it repeatedly in its text. Promiscue, it speaks, this time both in the title and the text, about 'persons reporting on breaches of Union law', which is the most general definition of whistleblowers provided in the Directive. Article 4 specifies that the Directive shall apply to 'reporting persons working in the private or public sector who acquired information on breaches in a work-related context', giving examples of such context.

Similar definitions are provided by other international organisations, even if they do not have binding instruments on whistleblowers. The International Labour Organization (ILO) defines whistleblowing as 'the re-

15 Id., 10.

$16 I d ., 6$.

17 Id., 8.

18 See Near and Miceli, 'Organizational Dissidence: The Case of Whistle-Blowing' (1985) 4J. Bus. Ethics, 1; Vaughn, Whistleblowing Law (2015).

19 Directive (EU) 2019/1937 of the European Parliament and of the Council of 23 October 2019 on the protection of persons who report breaches of Union law. 
porting by employees or former employees of illegal, irregular, dangerous or unethical practices by employers'. ${ }^{20}$ For the CoE, a whistleblower is 'any person who reports or discloses information on a threat or harm to the public interest in the context of their work-based relationship, whether it be in the public or private sector'. ${ }^{21}$ International conventions dealing with the fight against corruption, while not using the term expressly, also deal with this phenomenon. The UN Convention against Corruption contains a provision on the protection of reporting persons whom it defines as 'any person who reports in good faith and on reasonable grounds to the competent authorities any facts concerning offences established in accordance with this Convention' (Article 33). The CoE Civil Law Convention on Corruption obliges States to protect 'employees who have reasonable grounds to suspect corruption and who report in good faith their suspicion to responsible persons or authorities' (Article 9).

The definition of whistleblowers again contains several elements. The first pertains to the actors, i.e. who whistleblowers are. They are all individuals who are in possession of relevant information and who report this information, regardless of whether they are active in the private or public sector. The reference to individuals or persons suggests that unlike human rights defenders, whistleblowers are natural persons, not legal entities, let alone international organisations or States. The second element concerns the activity, i.e. what whistleblowers do. They report - inside their institution or through public channels - activities that are considered illegal or immoral. Some definitions moreover require that the reported wrongdoing be of a serious nature or public interest, narrowing the acts which may qualify as whistleblowing. The third element relates to the context, i.e. where whistleblowers act. They act in a work-related context. They tend to have a privileged status within the institution that allows them to get access to confidential, inside information regarding the activities of this institution or individuals within it. As the ECtHR held in Medžlis Islamske Zajednice Brčko, such a privileged position entails a special duty of 'loyalty, reserve and discretion'22 that whistleblowers have with respect to their institution and that they may break to be able to report unethical

20 International Labour Organization, International Labour Organization Thesaurus (2005) (the ILO Thesaurus is a compilation of terms relating to the world of work).

21 CoE Committee of Ministers, Protection of Whistleblowers, 30 April 2014, Recommendation $\mathrm{CM} / \operatorname{Rec}(2014) 7$, definition a.

22 ECtHR, Judgment (GC), 27 June 2017, Medžlis Islamske Zajednice Brčko v Bosnia and Herzegovina, Application No. 17224/11, para. 80. 
or unlawful behaviour. Those reporting wrongdoings outside the working context, based on information acquired from public sources, would not be whistleblowers. Some of them may qualify as human rights defenders.

\section{What are the Shared Features and the Differences between the two Groups?}

Human rights defenders and whistleblowers are two distinct categories. The differences between them relate to all the elements of the definitions identified above. First, concerning the actors: whereas whistleblowers are individuals, the circle of human rights defenders is broader, encompassing also groups, associations and, even, State bodies and organs of international organisations. Secondly, as to the activity: whistleblowers report on unlawful or unethical activities identified within their institution; human rights defenders promote and protect universally recognised human rights and fundamental freedoms. The two groups thus engage in different activities (reporting vs promoting and protecting human rights) and they operate within different normative frameworks (legal or ethical standards vs human rights). ${ }^{23}$ Thirdly, with respect to the mode of operation and context: whistleblowers are limited to the work-related context, human rights defenders on the contrary have no $a$ priori limits imposed on them, apart from the peaceful nature of their activities.

Despite these differences, human rights defenders and whistleblowers share certain important features. They both act in general interest, helping prevent actions that are harmful not only (and not necessarily) to concrete human rights defenders or whistleblowers but to other persons, institutions and even the society at large. The nature of their activities makes human rights defenders and whistleblowers alike increasingly vulnerable to human rights and other abuses carried out with the purpose of silencing them. Due to this increased vulnerability, the two groups are both in need of special legal protection and have already been provided with such protection in international law, albeit mostly through soft law instruments. Although the concrete forms of abuses that human rights defenders and

23 There are, however, overlaps between the two categories. See CoE Parliamentary Assembly, Protection of “whistle-blowers", 29 April 2010, Resolution 1729 (2010), which notes that the definition of protected disclosures 'shall include all bona fide warnings against various types of unlawful acts, including all serious human rights violations which affect or threaten the life, health, liberty and any other legitimate interests of individuals as subjects of public administration or taxpayers, or as shareholders, employees or customers of private companies' (para. 6.1.1). 
whistleblowers suffer differ somewhat from each other as does the legal framework applicable to them, the common characteristics which they share explain why this chapter brings the two categories together.

\section{B. How does the Increased Vulnerability of Human Rights Defenders and Whistleblowers Manifest Itself?}

Human rights defenders and whistleblowers engage in activities that are not welcomed by everyone. ${ }^{24}$ These activities tend to be particularly unpopular with those who get criticised for their participation in human rights abuses (by human rights defenders) or are reported on for their illegal or immoral activities (by whistleblowers). Since such persons or institutions are often in a position of power, they may seek to take steps that would prevent human rights defenders and whistleblowers from continuing their actions or punish them for carrying these actions out. Such steps may involve violations of human rights and various other abuses. ${ }^{25}$ The increased vulnerability to such violations and abuses manifest itself in three main areas. These areas relate to private life and safety (I.), the activities in the public space (II.), and the economic and social status, including the position at work (III.).

\section{Private Life and Safety}

Human rights defenders and whistleblowers may be subject to interferences with their private life and safety. ${ }^{26}$ The degree of their vulnerability depends on the type of activities they engage in, the nature of wrongdoings/wrongdoers they expose, the political system of the country where

24 See also OSCE, Human Rights Defenders in the OSCE Region: Challenges and Good Practices (2008).

25 In the classical approach, human rights may only be violated by acts carried out by or attributable to States. Under the doctrine of horizontal effects, States may also be held accountable for acts of private actors if they fail to take adequate measures to prevent or repress such acts. See Alston (ed), Non-State Actors and Human Rights (2005); Lane, 'The Horizontal Effect of International Human Rights Law in Practice: A Comparative Analysis of the General Comments and Jurisprudence of Selected United Nations Human Rights Treaty Monitoring Bodies' (2018) 5 EJCL, 5.

26 See OSCE, Guidelines on the Protection of Human Rights Defenders (2014), 3 ff.; Alford, Whistleblowers: Broken Lives and Organizational Power (2002). 
they live as well as their own personal features and social status. While all human rights defenders and whistleblowers are vulnerable, some are more vulnerable than others. For instance, women may face an increased risk of rape and sexual harassment, people with dependent children may be vulnerable to blackmailing through their children, etc. It is important to keep in mind that interferences may go on for a protracted period of time. Even relatively minor nuisances, which would not do much harm on their own, may, if they occur on a regular basis, have a heavy impact on the targeted persons and their families.

The most extreme forms of threats concern life and physical integrity as protected by Articles 2, 3 and 5 of the ECHR. The 2019 global report by the NGO Front Line Defenders indicates that more than 300 human rights defenders were killed all over the world that year alone. ${ }^{27}$ Most of them were attacked by (allegedly) unknown perpetrators, abducted and subsequently murdered, or simply disappeared without any traces. ${ }^{28}$ Hundreds of defenders get seriously injured, kidnapped, mistreated and subjected to inhuman treatment or even torture. ${ }^{29}$ While less commonly, whistleblowers become targets of violent actions threatening their life as well. ${ }^{30}$ Human rights defenders and whistleblowers alike are also exposed to death threats addressed to them or to members of their family. ${ }^{31}$ Death threats, in fact, seem to be one of the most 'popular' means of intimidating persons who engage in 'undesirable' activities. Easy to make, especially with the recent spread of social media, they also tend to be taken much less seriously by law enforcement agencies than actual attacks. Yet, as noted by the UN OHCHR, 'death threats [...] can oblige human rights defenders to change their daily routines completely, as well as those of their immediate family, or even to leave their country to seek temporary asylum abroad'. ${ }^{32}$

27 See Front Line Defenders, Front Line Defenders Global Analysis 2019 (2020), 7.

28 For instance, in recent years, the investigative journalists Daphne Caruana Galizia (2017) and Ján Kuciak (2018) have been killed in Malta and Slovakia, respectively.

29 Front Line Defenders, Front Line Defenders Global Analysis 2019 (2020).

30 The Times of India, RTI activists abducted and tortured, 26 December 2013.

31 UN General Assembly, Final warning: death threats and killings of human rights defenders. Report of the Special Rapporteur on the situation of human rights defenders, Mary Lawlor, 24 December 2020, UN Doc. A/HRC/46/35; mLIVE, Michigan man made death threat to Trump whistleblower's attorney, feds say, 22 February 2020, https://www.mlive.com/news/saginaw-bay-city/2020/02/michigan-man-made-deat h-threat-to-trump-whistleblowers-attorney-feds-say.html.

32 UN OHCHR, Human Rights Defenders: Protecting the Right to Defend Human Rights. Fact Sheet No. 29 (2004), 11. 
Female human rights defenders and whistleblowers are more likely to be exposed to sexual abuses including rape than their male counterparts, though the latter are not immune to this type of abuse either. ${ }^{33}$ Abuses may be committed by public officials, violent non-state actors but also, not unfrequently, by members of their own family or community, seeking to discipline and silence 'trouble-makers'. Human rights defenders and whistleblowers focusing on certain issues, typically women's reproductive rights or LGBT+ rights, or reporting on certain types of abuses, such as rape and sexual violence, are particularly vulnerable to sexual abuse. ${ }^{34}$ Other forms of harassment are also commonplace, and they often go unreported or if reported, un-investigated. Individuals get repeatedly monitored without obvious reasons, have fines imposed on them for trivial transgressions, have to present themselves at regular intervals to the police, have their private mails, emails and phone calls read and wiretapped, etc. ${ }^{35}$ These practices not only interfere with the private life, but they may also have an impact on the state of the mental and physical health of those targeted and their families.

Closely related to these abuses are the encroachments upon personal liberty. ${ }^{36}$ Arbitrary arrests and detentions are not uncommon, and they often occur in the absence of official charges. Sometimes, fake trials or trials for acts that should not constitute criminal offences in a democratic society (social parasitism, distributing prohibited books, etc.) are arranged, resulting in humiliating sanctions (forcible commitment to psychiatric institutions, re-education through labour, etc.). ${ }^{37}$ This applies to human rights defenders and to whistleblowers alike. The latter may face charges of betrayal of state secrets, high treason, espionage, collusion with the

33 UN General Assembly, Situation of human rights defenders. Note by the Secretary-General, 16 July 2020, UN Doc. A/75/165, para. 48; Hunt, 'The Challenges Women Whistleblowers Face' (2010) 3(2) International Business Research, 3.

34 Mulé, 'LGBTQI-identified human rights defenders: courage in the face of adversity at the United Nations' (2018) 26(1) Gender and Development, 89.

35 See Inter-American Commission on Human Rights, Report on the Situation of Human Rights Defenders in the Americas, 17 March 2006, OEA/Ser.L/V/II.124/Doc. 5 rev.1, paras. $164 \mathrm{ff}$.

36 CoE, Human Rights Defenders in the Council of Europe Area: Current Challenges and Possible Solutions. Report from the Round-Table with human rights defenders organised by the Office of the CoE Commissioner for Human Rights (Helsinki, 13-14 December 2018), 29 March 2019, CommDH(2019)10, paras. $14 \mathrm{ff}$.

37 Inter-American Commission on Human Rights, Report on the Situation of Human Rights Defenders in the Americas, 17 March 2006, OEA/Ser.L/V/II.124/Doc. 5 rev.1, paras. $174 \mathrm{ff}$. 
enemy or similar charges which tend to entail high penalties. For instance, Edward Snowden, who leaked highly classified information from the US National Security Agency in 2013, has been charged with theft of government property, unauthorised communication of national defence information and wilful communication of classified intelligence information to an unauthorised person. ${ }^{38}$ In some instances, whistleblowers are charged with common offences and it might be difficult to say whether the prosecution is politically motivated. This is the case of another well-known whistleblower, Julian Assange, the founder of WikiLeaks, wanted in Sweden in connection with the accusations of rape and sexual molestation. ${ }^{39}$

Many measures directed against human rights defenders and whistleblowers target their private and family life. Defamation campaigns are a popular instrument used to question the moral integrity and tarnish the reputation of those who have engaged in undesired criticism. Human rights defenders ${ }^{40}$ and whistleblowers ${ }^{41}$ are labelled as traitors, subversive elements, lazy and parasitic individuals or, in the recent years, as terrorists. They are accused of betraying their country and serving foreign interests and described as immoral persons. Their private space is often disrespected - their homes and business premises get surveyed and searched, their private or business communication read or wiretapped, their personal data may be stored for extended periods of time. ${ }^{42}$ The pressure is often directed not only against human rights defenders and whistleblowers themselves but also against members of their family, including underage children.

38 Davis, 'Is Edward Snowden Protected By International Law?', Huffington Post, 17 July 2013, https://www.huffpost.com/entry/edward-snowden-international-law_n 3544679 .

39 See Melzer, State Responsibility for the Torture of Julian Assange, Speech by Nils Melzer, UN Special Rapporteur on Torture, at the German Bundestag in Berlin, 27 November 2019 (English translation), 16 December 2019, https://medium.com/@nj melzer/state-responsibility-for-the-torture-of-julian-assange-40935ea5d7c3.

40 UN General Assembly, Situation of human rights defenders. Note by the Secretary-General, 10 August 2012, UN Doc. A/67/292, paras. $15 \mathrm{f}$.

41 Papandrea, 'Leaker Traitor Whistleblower Spy: National Security Leaks and the First Amendment' (2014) 94(2) Boston Univ Law Rev, 449.

42 See Frost, World Report on the Situation of Human Rights Defenders, December 2018. 


\section{Activities in the Public Space}

Human rights defenders and, to a lesser extent, whistleblowers face human rights abuses not only in their private life but also in the public space. Virtually all civil and political rights may get interfered with by State agents or non-state actors acting with the State's express or implicit support. ${ }^{43}$ Free speech and access to information, protected under Article 10 of the ECHR, are among such rights. Since human rights defenders and whistleblowers say or write things that are not pleasant to hear or read by those concerned, the attempts to prevent them from being able to get access to information and to spread this information and attempts to punish them, if they succeed to do so, are common. ${ }^{44}$ As the ultimate aim of measures directed against human rights defenders and whistleblowers is to silence them, their exercise of the right to freedom of expression is virtually always at stake. Steps taken to silence human rights defenders and whistleblowers do not only interfere with the rights of those persons but also with the legitimate interest of the general public to know about illegal and immoral activities carried out in the public or private sector. Media play a particularly important role in this field, both as actors monitoring human rights in the country and as a means through which information about human rights abuses and other wrongdoings may be made accessible to the general public. ${ }^{45}$

Another right, which is often interfered with in this context, is the right to freedom of association, guaranteed by Article 11 of the ECHR. As we have seen, while whistleblowers are natural persons, human rights defenders may be, and often are, collective entities, typically NGOs. Such entities may get targeted by various legal, administrative and other measures that make it difficult for them to engage in their standard activities. For example, their creation becomes subject to various burdensome conditions that are not easy to meet. Once established, they have more obligations than

43 States may be held responsible for human rights abuses by non-state actors that are attributable to them. They may also be held responsible for their own failure to prevent human rights abuses committed by non-state actors. See also Hessbruegge, 'Human Rights Violations Arising from Conduct of Non-State Actors' (2005) 11 Buff Hum Rts L Rev, 21.

44 See UN General Assembly, Promotion and protection of the right to freedom of opinion and expression. Note by the Secretary-General, 8 September 2015, UN Doc. $\mathrm{A} / 70 / 361$.

45 Mitchell, 'Journalists as Human Rights Defenders: International Protection of Journalists in Contexts of Violence and Impunity' in Shaw and Selvarajah (eds), Reporting Human Rights, Conflicts, and Peacebuilding (2019), 221. 
other legal persons, e.g., the obligation to report about their activities or financial situation more frequently. ${ }^{46}$ They are also often cut from certain sources of funding, especially funding from abroad. Or, if they are allowed to receive such funding, they may have to use problematic labels such as 'foreign agents'. ${ }^{47}$ Their premises get regularly checked for unclear reasons and their internal documents are confiscated. Finally, the organization may get dissolved for minor transgressions, for instance for the failure to produce a certain document in time or minor discrepancies in the financial or membership reports. ${ }^{48}$

Other forms of interferences concern the rights to freedom of assembly, freedom of movement, freedom of religion, or freedom to vote and take part in public affairs. All these rights are guaranteed in the ECHR (Articles 10 and 11) and its Protocols (Article 3 of Protocol No. 1, Article 2 of Protocol No. 4). Individuals taking part in 'undesired' activities are prevented from holding public meetings or taking part in them. Alternatively, they are detained during such meetings and accused of various transgressions. ${ }^{49}$ Human rights defenders also get prevented from travelling to places where they could investigate or simply witness human rights abuses. They may also be prohibited to leave the country or, on the contrary, forced to do so, and then prevented from returning. ${ }^{50}$ Defenders may also face difficulties in access to religious services. Quite often, they find it uneasy to exercise the right to vote and the right to take part in public affairs. ${ }^{51}$ The public authorities do not only fail to consult them and civil society more broadly about questions of public interest, but they also actively seek to prevent them from being able to take part in any public discussions. Whistleblow-

46 Amnesty International, Global assault on NGOs reaches crisis point as new laws curb vital human rights work, 21 February 2019.

47 Venice Commission, Report on funding of associations, 18 March 2019, CDL$\mathrm{AD}(2019) 002$. See also Pfeffer, Why Breaking the Silence Became the Most Hated Group in Israel, Haaretz, 17 December 2015.

48 Venice Commission-OSCE/ODIHR, Joint Guidelines on Freedom of Association, 17 December 2014, CDL-AD(2014)046.

49 Front Line Defenders, Arrests of human rights defenders threaten rights to freedom of assembly and expression in Hong Kong, 20 April 2020, https://www.front linedefenders.org/en/statement-report/arrests-human-rights-defenders-threaten-rig hts-freedom-assembly-and-expression-hong.

50 Front Line Defenders, \#Travel Ban, 2021, https://www.frontlinedefenders.org/en/ violation/travel-ban.

51 Front Line Defenders, Judicial harassment of human rights defenders in the lead-up to presidential elections, 19 May 2020, https:/www.frontlinedefenders.or $\mathrm{g} / \mathrm{en} /$ statement-report/judicial-harassment-human-rights-defenders-lead-presidenti al-elections. 
ers might have similar difficulties in the access to the management of the institutions within which they operate.

\section{Economic and Social Status}

Human rights abuses committed against human rights defenders and whistleblowers are not limited to civil and political rights. Curtailing their economic, social and cultural rights, recognized and protected in the International Covenant on Economic, Social and Cultural Rights, the European Social Charter and, partly, the ECHR, might be as effective a way to dissuade them from engaging in their activities or to sanction them for doing so. ${ }^{52}$ Human rights defenders and whistleblowers, as well as members of their family, have their property confiscated or destroyed, get evicted from their homes and may be, as mentioned above, banned from accepting funding from certain sources. Preventing their or their family members' access to health or social services and to schools is also rather frequent and may be particularly 'efficient' in countries where these services are provided predominantly or exclusively by the State. For instance, in the pre-1990 communist regimes, children of dissidents were denied access to universities and could have difficulties with access to certain social benefits. ${ }^{53}$

Human rights defenders and whistleblowers are also vulnerable to retaliatory measures at work. Here, their respective positions differ. Whereas human rights defenders usually do not have any special work relationship to those whose activities they criticise, whistleblowers, who report on wrongdoing committed by their colleagues, superiors or their institution, do have such a relation. That renders them exposed to an increased risk of retaliation by their employers. Whistleblowers may be sanctioned for disciplinary offences or lack of loyalty, deposed from their current position or dismissed altogether, and they may have troubles finding a new job. For instance, Jeffrey Wigand, an American biochemist and the head of research and development at a major tobacco company, who exposed on TV the toxicity of the tobacco produced by his company, was immediately fired

52 UN Committee on Economic, Social and Cultural Rights, Human rights defenders and economic, social and cultural rights, 29 March 2017, UN Doc. E/C.12/2016/2.

53 See Powell, 'Controlling Dissent in the Soviet Union' (1972) 7(1) Government and Opposition, 85. 
(and received anonymous death threats). ${ }^{54}$ Human rights defenders may be exposed to such threats as well, especially in countries where the State is the main employer and where assigning a low-paid job with no social prestige is used as a sanction. ${ }^{55}$ Yet, while for whistleblowers, work-related measures are the main instrument of pressure, for human rights defenders, they are usually but one from a more extensive set of such instruments.

\section{Increased Vulnerability of Human Rights Defenders and Whistleblowers}

As we have seen in the previous subparts, human rights defenders and whistleblowers are vulnerable to human rights abuses committed or tolerated by States. These abuses may affect them in many areas of their lives - they may have their privacy disrespected, their safety jeopardized, their activities in the public space disrupted and their voices silenced. They may also lose their job, be deprived of property or be denied access to education, health care and social services. They may be targeted directly or through family members or friends. In all cases, the aim is to prevent them from monitoring, and reporting on, human rights violations and from disclosing facts about illegal or immoral activities, or to retaliate against them for having done so. Moreover, as the OHCHR recalls, the 'violations of the rights of human rights defenders have been compounded by a culture of impunity which exists in many countries in relation to acts committed against human rights defenders'. ${ }^{56}$ The same holds true, albeit to a lesser extent, for whistleblowers who may be left unprotected from the wrath of the person or institution whose wrongdoings they have reported. The increased vulnerability of the two categories has not gone unnoticed. It is at the source of several international instruments, and it has found reflection in international case-law that will be discussed in the next part.

54 Lyman, 'A Tobacco Whistle-Blower's Life Is Transformed', New York Times, 15 October 1999 https:/www.nytimes.com/1999/10/15/us/a-tobacco-whistle-blower-s -life-is-transformed.html.

55 Maldives Independent, Rilwan and Yameen's relatives fired for joining protest march, 16 August 2017, https://maldivesindependent.com/society/rilwan-and-yam eens-relatives-fired-for-joining-protest-march-132039.

56 UN OHCHR, Human Rights Defenders: Protecting the Right to Defend Human Rights. Fact Sheet No. 29 (2004), 13. 


\section{Legal Regulations Applicable to Human Rights Defenders and Whistleblowers}

In principle, human rights defenders and whistleblowers enjoy the same legal protection as other individuals or, in case of NGOs, as other associations. The full range of human rights granted in general human rights instruments, such as the ECHR, apply to them. In addition, over the past three decades, several instruments dealing specifically with these two groups have been adopted. These instruments, often non-binding in nature (soft law). do not introduce any new human rights. What they do, rather, is to specify how general human rights are to be implemented, applied and interpreted in the specific context of human rights defenders and whistleblowers. International human rights bodies, such as the ECtHR, have also contributed to this specification. Although human rights defenders and whistleblowers are exposed to similar human rights abuses, due to the differences between them, described in Part A, legal standards applicable to them are not, and cannot be, completely identical. This part provides an overview of such standards, focusing first on human rights defenders (I) and then on whistleblowers (II).

\section{Legal Standards Applicable to Human Rights Defenders}

There is no legally binding instrument that would focus specifically on human rights defenders. The most authoritative, albeit non-binding source is the 1998 UN Declaration on Human Rights Defenders. ${ }^{57}$ The Declaration was elaborated over a 14-year period, which had begun in 1984 when the UN Human Rights Commission had decided to establish an open-ended working group on this topic. ${ }^{58}$ The final text was adopted by the UN General Assembly, without vote, on 9 December 1998, on the occasion of the 50th anniversary of the Universal Declaration of Human Rights. It is based on legal standards that are contained in binding treaties, mainly the UN International Covenants on Civil and Political Rights and on Economic, Social and Cultural Rights. The Commentary on the Declaration, drafted

57 UN General Assembly, Declaration on the Right and Responsibility of Individuals, Groups and Organs of Society to Promote and Protect Universally Recognized Human Rights and Fundamental Freedoms, 8 March 1999, UN Doc. A/RES/53/144.

58 UN Commission on Human Rights, Report on the Fortieth Session (6 February-16 March 1984), UN Doc. E/1984/14(SUPP)-E/CN.4/1984/77, 108. 
by the UN Special Rapporteur on Human Rights Defenders, confirms that 'the Declaration specifies how the rights included in major human rights instruments apply to human rights defenders and their work'. ${ }^{59}$ It also stresses that the Declaration 'was adopted by consensus [...], which consequently represents States' strong commitment towards its implementation'. ${ }^{60}$

The UN Declaration starts from the premise that 'everyone has the right, individually and in association with others, to promote and to strive for the protection and realization of human rights and fundamental freedoms at the national and international levels' (Article 1). The promotion and protection of human rights is thus not left to States, international institutions or members of any special profession. It is, as the official title of the Declaration expresses, the right and responsibility of everyone. The substantive provisions of the UN Declaration (Articles 2-18) specify the rights that human rights defenders enjoy as well as the duties that arise with respect to these rights. The duties mostly fall upon States, though occasionally, other actors are addressed as well. For instance, Article 11 calls upon those 'who, as a result of [their] profession, can affect the human dignity, human rights and fundamental freedoms of others' to 'respect those rights and freedoms and comply with relevant national and international standards of occupational and professional conduct or ethics'. The provision applies, for instance, to judges, advocates, police officers or medical staff.

The rights of human rights defenders listed in the Declaration include the rights to form associations; to meet or assemble peacefully; to seek, obtain, receive and hold information relating to human rights; to make complaints about official policies and acts relating to human rights and to have such complaints reviewed; or to solicit, receive and utilise resources for the purpose of protecting human rights. The Declaration thus mainly focuses on challenges that human rights defenders face in the public space. The other human rights abuses listed in Part B of this chapter, such as the interference with private life or the denial of economic and social rights, are either not addressed at all, or only indirectly. ${ }^{61}$ The duties of States are

59 UN OHCHR, Commentary to the Declaration on the Right and Responsibility of Individuals, Groups and Organs of Society to Promote and Protect Universally Recognized Human Rights and Fundamental Freedoms (2011), 5 footnote 1.

60 Ibid.

61 The indirect protection could be granted, for instance, through the right to benefit from an effective remedy and to be protected in the event of the violation of human rights (Article 9(1) of the UN Declaration). 
drafted in more general terms, encompassing the duty to protect, promote and implement all human rights; the duty to provide an effective remedy for persons who claim to be victims of a human rights violation; the duty to conduct prompt and impartial investigations of such alleged violations; or the duty to take all necessary measures to ensure the protection of everyone against any violence, threats, retaliation or other arbitrary action as a consequence of his or her legitimate exercise of the rights referred to in the Declaration. Some of these obligations, e.g. the duty to protect, promote and implement human rights, are broad enough to extend to all abuses that human rights defenders might suffer.

The UN Declaration is the most important international instrument concerning human rights defenders. It is not, however, the only one. In the 2000s, the Council of the EU and the CoE Committee of Ministers issued non-binding documents on the same topic, which, in fact, elaborate upon the Declaration. The two documents - the 2004 EU Guidelines on Human Rights Defenders ${ }^{62}$ and the 2008 Declaration on Council of Europe action to improve the protection of human rights defenders and promote their activities ${ }^{63}$ - both concentrate on the responsibilities that the relevant organisation, its member States and some other actors have with respect to human rights defenders.

The 2008 CoE Declaration takes a traditional approach, focusing on the responsibilities 'at home', i.e. in each $\mathrm{CoE}$ member State's respective territory. The Declaration condemns attacks on and violations of human rights of human rights defenders in the member States. It calls upon these States to take measures to prevent, stop and/or sanction such attacks and violations and to generally 'create an environment conducive to the work of human rights defenders' (para. 2-i). The 2004 EU Guidelines, on the contrary, deal with the situation of human rights defenders 'outside', i.e. in non-EU States. It is a tool of the common foreign and security policy, which is supposed to help the EU work 'towards the promotion and protection of human rights defenders in third countries' (para. 7). The EU does not have a similar instrument to help it work towards this goal 'at home'. It is probably assumed that such an instrument is not really needed or that the area is adequately covered by existing instruments (the ECHR

62 Council of the EU, Ensuring Protection - European Union Guidelines on Human Rights Defenders, 1 December 2008, 16332/1/08. See also Bennett, 'European Union Guidelines on Human Rights Defenders: a review of policy and practice towards effective implementation' (2015) 19(7) IJHR, 908.

$63 \mathrm{CoE}$ Committee of Ministers, Declaration on Council of Europe action to improve the protection of human rights defenders and promote their activities, 6 February 2008. 
and the UN and CoE Declarations). Whether this assumption is warranted is open to debate.

In addition to these instruments, various resolutions on human rights defenders have been adopted by the UN, the $\mathrm{CoE}$ and other international organisations. ${ }^{64}$ The UN Special Rapporteur on the situation of human rights defenders, whose mandate was established in 2000, has also played an important role in this area. Through his/her regular reports, s/he has drawn attention to the challenges faced by human rights defenders, proposed measures that should be taken to improve the situation and provided examples of best practice. ${ }^{65}$ Particularly interesting among these reports are those submitted in February 2016 and July 2018. The former ${ }^{66}$ identifies instances of good practices in the protection of human rights defenders at the local, national, regional and international levels. The focus lies in three areas, namely strengthening the resources and capacities of defenders, fostering an enabling environment for the defence of their rights and supporting their protection. The report contains a set of seven principles on which the protection of human rights defenders shall be based (rights-based approach, diversity, gender sensitivity, holistic security, interconnectedness, participation, flexibility). ${ }^{67}$ The latter report ${ }^{68}$ analyses the outcomes of a global survey covering 140 States, which was carried out at the occasion of the $20^{\text {th }}$ anniversary of the adoption of the UN Declaration. The survey showed that although measures aimed at increasing the protection of human rights defenders had been adopted in many parts of the world, new challenges had also arisen, and defenders remained under serious threats. The Special Rapporteur formulated a set of recommendations, addressed to various actors at the national and international level,

64 See, for instance, UN General Assembly, Promotion of the Declaration on the Right and Responsibility of Individuals, Groups and Organs of Society to Promote and Protect Universally Recognized Human Rights and Fundamental Freedoms: protecting women human rights defenders, 18 December 2013, UN Doc. A/RES/68/181; CoE Parliamentary Assembly, The situation of human rights defenders in Council of Europe member States, 27 June 2012, Resolution 1891 (2012).

65 See UN OHCHR, Special Rapporteur on the situation of human rights defenders, 2021, https:/www.ohchr.org/EN/Issues/SRHRDefenders/Pages/SRHRDefendersI ndex.aspx.

66 UN Human Rights Council, Report of the Special Rapporteur on the situation of human rights defenders. Note by the Secretariat, 1 February 2016, UN Doc. $\mathrm{A} / \mathrm{HRC} / 31 / 55$.

67 Id., para. 111.

68 UN General Assembly, Situation of human rights defenders. Note by the Secretary-General, 23 July 2018, UN Doc. A/73/215. 
that should help counter these threats and that encompass, unsurprisingly, the full respect of the UN Declaration.

Over the years, international human rights bodies have been repeatedly confronted with cases involving human rights defenders. The ECtHR has been at the frontline of this effort. Through its case-law, it has contributed to the clarification of the legal standards applicable in this area. As of January 2021, the HUDOC database renders 45 decisions that contain explicit references to human rights defenders. Certain other decisions that do not use the term deal with the group as well. ${ }^{69}$ Most of the decisions are directed against four countries - Russia (22), Azerbaijan (7), Armenia (6) and Turkey (4). The provisions of the ECHR most frequently concerned are Articles 3 (prohibition of torture and inhuman treatment), 5 (right to liberty and security), 6 (right to a fair trial) and 13 (right to effective remedies). In virtually all cases where the application was not declared inadmissible, the ECHR has found at least one violation of the ECtHR - Articles 3 and 5 come at the top of the violated provisions, followed by Articles 6,13 and also 10 (freedom of expression) and 11 (freedom of assembly and association).

Among the best-known cases are those concerning the situation in Azerbaijan. In the Aliyev Case (2008), ${ }^{70}$ the Court considered the application of a leading Azeri human rights defender, who had been arrested and charged with financial offences. It found violations of Articles 3 (inhuman and degrading conditions of detention), 5 (unlawful deprivation of liberty), 8 (search and seizure at the applicant's home and office with no legitimate purpose) and also 18 (restrictions imposed for other than legitimate purposes) of the ECHR. The Court referred several times to international instruments on human rights defenders. It stressed that it attached

particular importance to the special role of human-rights defenders in promoting and defending human rights, including in close cooperation with the Council of Europe, and their contribution to the protection of human rights in the member States. ${ }^{71}$

Noting that the facts showed that there had been a larger campaign against human rights defenders in Azerbaijan, it also called upon the country to

69 This is for instance the case in Alekhina and Others $v$ Russia in which the ECtHR considered the application of the group 'Pussy Riot'. See ECtHR, Judgment, 17 July 2018, Mariya Alekhina and Others $v$ Russia, Application No. 38004/12.

70 ECtHR, Judgment, 20 September 2018, Aliyev v Azerbaijan, Application Nos. $68762 / 14$ and $71200 / 14$.

71 Id., para. 208. 
adopt general measures to improve the situation of human rights defenders and protect them from retaliatory prosecutions and misuse of criminal law. More recent case-law shows that so far these measures have not been adopted and human rights defenders remain at risk in Azerbaijan. ${ }^{72}$

The special position of human rights defenders has been further elaborated upon by the ECtHR in Kavala $v$ Turkey (2019). ${ }^{73}$ The decision contains over 50 references to the term and quotes several CoE instruments adopted in this area, including the $2008 \mathrm{CoE}$ Declaration. The case concerned a Turkish human rights defender and philanthropist who challenged his arbitrary arrest and placement in pre-trial detention carried out in the aftermath of the 2016 failed coup. The applicant argued that he was specifically targeted as a human rights defender and that his detention pursued the purposes of silencing him and dissuading others from engaging in the promotion and protection of human rights. Turkey contested this argument suggesting that while the applicant was indeed a human rights defender, his detention was in no way linked to this qualification. The ECtHR sided with the applicant concluding that

it has been established beyond reasonable doubt that the measures complained of in the present case pursued an ulterior purpose, $[\ldots]$ namely that of reducing the applicant to silence. Further, [...] the contested measures were likely to have a dissuasive effect on the work of human-rights defenders. ${ }^{74}$

In light of this conclusion, the Court found violations of Articles 5 and 18 of the ECHR.

The decisions suggest that the ECtHR recognises the special position of human rights defenders, their increased vulnerability and the need to consider their cases in light of the chilling effect that measures taken against them might have on civil society at large. This approach has translated into a rather extensive use of Article 18 of the ECHR, through which the Court casts doubt as to whether measures directed again human rights defenders pursued legitimate aims or, rather, were adopted for ulterior purposes, those of intimidating civil society and silencing dissenting voices. At the same time, the Court has not found it necessary to discuss the concept of human rights defenders at any length and it has also only rarely referred

72 See ECtHR, Judgment, 16 July 2020, Yunusova and Yunusov v Azerbaijan (No. 2), Application No. 68817/14.

73 ECtHR, Judgment, 10 December 2019, Kavala $v$ Turkey, Application No. $28749 / 18$.

74 Id., para. 232. 
to international instruments on human rights defenders. For instance, the UN Declaration on Human Rights Defenders is mentioned in a single case $^{75}$ and even there, it is just listed in the section providing an overview of international material on human rights defenders. This suggests that for the moment, international instruments on the one hand and the ECtHR case-law on the other operate more as two parallel and largely independent tracks pursuing the common goal of enhancing legal protection of human rights defenders, than as pieces of a uniform and internally coherent protective system.

\section{Legal Standards Applicable to Whistleblowers}

Whereas the protection of human rights defenders has received attention for more than two decades now, the protection of whistleblowers has started to be taken seriously only recently. Despite this fact, there already is a legally binding instrument, albeit a regional one, applicable to whistleblowers. It is the EU Whistleblower Protection Directive ${ }^{76}$ adopted in 2019. A directive is an EU legal act that binds the member States as to the goals they have to achieve but leaves it up to them to choose the means to do so. ${ }^{77}$ Yet, some directives are so detailed that the space left to States is relatively limited. This is the case with the EU Whistleblower Protection Directive.

The purpose of the Directive is 'to enhance the enforcement of Union law and policies in specific areas by laying down common minimum standards providing for a high level of protection of persons reporting breaches of Union law' (Article 1). These standards should guide States in the implementation and should serve as the minimum common denominator, which nonetheless is not so minimum after all. The Directive sets up rules for both internal and external reporting and follow-up as well as for public disclosure. These procedures are understood as gradual, subsidiary steps in the reporting/disclosing process. Whistleblowers should, unless this is

75 ECtHR, Judgment, 20 September 2018, Aliyev v Azerbaijan, Application Nos. $68762 / 14$ and $71200 / 14$, para. 88.

76 Directive (EU) 2019/1937 of the European Parliament and of the Council of 23 October 2019 on the protection of persons who report breaches of Union law. See also Popescu, 'A Critical Analysis of Whistleblower Protection in the European Union' (2015) 7 JOPAFL, 135.

77 The majority of the provisions of the Directive shall be implemented by 17 December 2021. 
impossible or impractical, first act within their institution, then through external channels (authorities designated in individual countries) and only as a last step reveal their information directly to the public.

In addition to providing basic rules on the mechanisms that should be put in place for whistleblowers to be able to act, the Directive also contains a special chapter on protection measures. This chapter calls upon States to take the necessary measures to prohibit, prevent and sanction any form of retaliation against whistleblowers, regardless of whether they act in the public or private sector. The examples of such retaliatory acts provided in Article 19 are quite diverse and include demotion, dismissal, a negative employee reference, coercion, harassment and psychiatric or medical referrals. Thus, although the provision primarily relates to the position at work, it takes account of the sanctions that whistleblowers may be exposed to outside their institution, e.g. in their private life. The Directive moreover confirms that whistleblowers shall not incur liability in respect of their activities (Article 21). If they face criminal, civil or disciplinary charges, they have the right to a fair trial (Article 22). They also have the right to effective remedies, which should apply to any case of human rights abuse that they become victims of. States have the duty to 'ensure that the rights and remedies [...] cannot be waived or limited by any agreement, policy, form or condition of employment, including a pre-dispute arbitration agreement' (Article 24), which makes the rights of whistleblowers to remedies 'non-derogable' in the work-related context. Although the Directive only applies to breaches of EU law, it is the first binding international instrument on whistleblowers and, as such, it constitutes an important milestone in the international protection of this group.

Independently of the EU, the Council of Europe has paid attention to whistleblowers, albeit without adopting a binding instrument. In 2010, the CoE Parliamentary Assembly adopted a resolution on whistleblowing, which sets the basic principles on which legislation related to whistleblowers should be based..$^{78}$ The Resolution stresses that whistleblowing should be regulated both in the private and public sectors and that States should opt for a broad definition of the term. The legislation should focus on 'providing a safe alternative to silence', ${ }^{79}$ making sure that channels of re-

78 CoE Parliamentary Assembly, Protection of "whistle-blowers", 29 April 2010, Resolution 1729 (2010). For more details, see Lewis, 'The Council of Europe Resolution and Recommendation on the Protection of Whistleblowers' (2010) 39(4) Industrial Law Journal, 432.

79 CoE Parliamentary Assembly, Protection of "whistle-blowers", 29 April 2010, Resolution 1729 (2010), para. 6.2. 
porting are available and that whistleblowers are protected against retaliation. In 2014, the Recommendation on the Protection of Whistleblowers ${ }^{80}$ was issued by the CoE Committee of Ministers. The recommendation has many similarities to the 2019 EU Directive, which certainly took inspiration from it. Yet, it is much less detailed, and it does not impose any legal obligations.

The ECtHR has dealt with the protection of whistleblowers in a limited number of cases (some 10 decisions in the HUDOC database). The best-known ones are Guja v Moldova (2008) ${ }^{81}$ and Medžlis Islamske Zajednice Brčko $v$ Bosnia and Herzegovina (2011), ${ }^{82}$ decided both by the Grand Chamber. The cases concerned the right to freedom of expression. In the former case, a civil servant was dismissed after revealing information of public interest on attempts by high-ranking politicians to influence the judiciary. In the latter case, several NGOs were fined for failing to verify the truthfulness of allegations they made in a letter addressed to local government concerning a candidate for a post as director of a public radio station. The Court concluded that the interference with Mr. Guja's right, i.e. his dismissal, constituted a violation of Article 10 of the ECHR. The interference with the NGOs' right, i.e. the fine imposed on them, was, on the contrary, compatible with the ECHR. The Court also indicated that whereas Mr. Guja could qualify as a whistleblower, the NGOs could not as they 'were not in any subordinated work-based relationship with the $\mathrm{BD}$ public radio $[\ldots]$ which would make them bound by a duty of loyalty, reserve and discretion towards the radio'. ${ }^{83}$

The ECtHR case-law has thus contributed to clarifying who whistleblowers are (and are not) and which measures may (and may not) be taken in response to their acts. The Court has made it clear that the two questions are closely related, i.e. the qualification of the applicant as a whistleblower affects the assessment of the legality of the interference with his/her rights. In Guja, the ECtHR introduced the main considerations that should guide this assessment, ensuring it reflects the special duty of loyalty, reserve and discretion that whistleblowers have towards their institution. Due to this duty,

80 CoE Committee of Ministers, Protection of Whistleblowers, 30 April 2014, Recommendation CM/Rec (2014) 7.

81 ECtHR, Judgment (GC), 12 February 2008, Guja v Moldova, Application No. $14277 / 04$.

82 ECtHR, Judgment (GC), 27 June 2017, Medžlis Islamske Zajednice Brčko v Bosnia and Herzegovina, Application No. 17224/11.

83 Id., para. 80 . 
Disclosure should be made in the first place to the person's superior or other competent authority or body. It is only where this is clearly impracticable that the information could, as a last resort, be disclosed to the public. ${ }^{84}$

In Medžlis Islamske Zajednice Brčko, where the applicants were not found to be whistleblowers, the ECtHR did not see any need to 'enquire into the kind of issue which has been central in the [...] case-law on whistleblowing, ${ }^{85}$ namely the obligation of the whistleblower to use the internal channels of reporting prior to going public. Similar to human rights defenders, the Court has only shown interest in international instruments on whistleblowers when it has referred to them in the section providing an overview of relevant international material. The conclusion reached in the previous section, that international instruments and the ECtHR case-law develop more in parallel than in interplay, thus seems applicable here as well.

\section{Conclusions}

Human rights defenders and whistleblowers show an increased vulnerability to human rights abuses. Due to the nature of activities, they engage in - monitoring and criticising human rights violations (human rights defenders) and disclosing information about unlawful or immoral activities within an institution (whistleblowers) -, they, or their family members, are subject to interferences with their private life, face threats to their safety, are prevented from engaging in activities in the public space, are denied the enjoyment of economic or social rights and have difficulties at work. Human rights defenders and whistleblowers enjoy the same human rights as any other individuals or legal persons. Yet, their increased vulnerability has made it necessary to specify how these rights should be implemented, applied and interpreted in their particular cases. For human rights defenders, this has happened through several non-binding instruments, especially the 1998 UN Declaration on Human Rights Defenders. For whistleblowers, the binding EU Whistleblower Protection Directive has recently been adopted, albeit only in the EU's regional framework.

84 ECtHR, Judgment (GC), 12 February 2008, Guja v Moldova, Application No. 14277/04, para. 73 .

85 ECtHR, Judgment (GC), 27 June 2017, Medžlis Islamske Zajednice Brčko v Bosnia and Herzegovina, Application No. 17224/11, para. 80. 
The two groups also feature in the case-law of the ECtHR, which has drawn particular legal consequences from the applicant qualifying as a human rights defender or a whistleblower. The former qualification makes the Court more careful in assessing the aims (allegedly) pursued by the interference with the applicants' rights and more willing to resort to Article 18 of the ECHR. The latter qualification makes the Court, in the assessment of the case, resort to special consideration whether 'internal channels of reporting' were exhausted by a whistleblower prior to him/her going public. When drawing these legal consequences, the ECtHR could easily rely on the available international instruments. ${ }^{86}$ Article 17 of the UN Declaration on Human Rights Defenders which stresses that restrictions on human rights of defenders may be adopted 'solely for the purpose of securing due recognition and respect for the rights and freedoms of others and of meeting the just requirements of morality', could underpin the use of Article 18 of the ECHR. The need to 'exhaust [...] internal channels of communication', stressed in CoE instruments, could be relied upon in cases concerning whistleblowing.. ${ }^{87}$ Yet, the ECtHR invokes neither of these provisions.

The legal standards applicable to human rights defenders and whistleblowers have thus developed through two parallel tracks - in international instruments and in case-law. The two tracks, fortunately, largely overlap in their scope and content. One may only hope that in the future, these two tracks will not depart from each other but will rather support each other more actively and explicitly in pursuing the common goal of improving the legal (and other) protection of persons who risk their well-being and sometimes also their life for the common good. One may also hope that the legal regime will take into account the full range of threats that human rights defenders and whistleblowers face, providing them with a truly comprehensive protection in all the three areas identified above (private life, public life, work) in which their increased vulnerability manifests itself.

86 The ECHR is only entitled to apply the ECtHR. Yet, it can rely on other legal instruments when interpreting the ECtHR, within the principle of systemic integration. See Rachovitza, 'The Principle of Systemic Integration in Human Rights Law' (2017) 66(3) International and Comparative Law Quarterly, 557.

87 CoE Parliamentary Assembly, Protection of "whistle-blowers", 29 April 2010, Resolution 1729 (2010), para. 6.2. 


\section{Bibliography}

Alford, C. Fred: Whistleblowers: Broken Lives and Organizational Power (2002).

Alston, Philip (ed): Non-State Actors and Human Rights (2005).

Amnesty International: Global assault on NGOs reaches crisis point as new laws curb vital

human rights work, 21 February 2019.

Bennett, Karen: European Union Guidelines on Human Rights Defenders: a review of policy

and practice towards effective implementation, The International Journal of Human Rights 2015, 908ff.

Bennett, Karen/Ingleton, Danna/Nah, Alice M./Savage, James: Critical perspectives on the security and protection of human rights defenders, The International Journal of Human Rights 2015, 883ff.

Davis, Carlo: Is Edward Snowden Protected By International Law?, Huffington Post, 17 July 2013, https://www.huffpost.com/entry/edward-snowden-internatio nal-law_n_3544679.

Donders, Yvonne: Defending the Human Rights Defenders, Netherlands Quarterly of Human Rights 2016, $282 \mathrm{ff}$.

Front Line Defenders: Arrests of human rights defenders threaten rights to freedom of assembly and expression in Hong Kong, 20 April 2020, https://www.fro ntlinedefenders.org/en/statement-report/arrests-human-rights-defenders-threaten -rights-freedom-assembly-and-expression-hong.

Front Line Defenders: Front Line Defenders Global Analysis 2019 (2020).

Front Line Defenders: Judicial harassment of human rights defenders in the leadup to presidential elections, 19 May 2020, https:/www.frontlinedefenders.org/e $\mathrm{n} /$ statement-report/judicial-harassment-human-rights-defenders-lead-presidential -elections.

Front Line Defenders: \#Travel Ban, 2021, https://www.frontlinedefenders.org/en/vi olation/travel-ban.

Frost, Michel: World Report on the Situation of Human Rights Defenders (2018).

Hessbruegge, Jan A.: Human Rights Violations Arising from Conduct of Non-State Actors, Buffalo Human Rights Law Review 2015, 21ff.

Hunt, Linda: The Challenges Women Whistleblowers Face, International Business Research 2010, $3 \mathrm{ff}$.

International Labour Organization: International Labour Organization Thesaurus (2005).

Inter-American Commission on Human Rights: Criminalization of the Work of Human Rights Defenders, OEA/Ser.L/V/II. Doc. 49/15, 31 December 2015.

Inter-American Commission on Human Rights: Report on the Situation if Human Rights Defenders in the Americas, OEA/Ser.L/V/II.124/Doc. 5 rev.1, 17 March 2006. 
Koula, Aikaterini Christina: The UN Definition of Human Rights Defenders: Alternative Interpretative Approaches, Queen Mary Human Rights Review 2019, $1 \mathrm{ff}$.

Landman, Todd: Holding the Line: Human Rights Defenders in the Age of Terror, The British Journal of Politics and International Relations 2016, $123 \mathrm{ff}$.

Lane, Lottie: The Horizontal Effect of International Human Rights Law in Practice: A Comparative Analysis of the General Comments and Jurisprudence of Selected United Nations Human Rights Treaty Monitoring Bodies, European Journal of Comparative Law and Governance 2018, $5 \mathrm{ff}$.

Lewis, David B.: The Council of Europe Resolution and Recommendation on the Protection of Whistleblowers, Industrial Law Journal 2010, 432ff.

Lyman, Rick: A Tobacco Whistle-Blower's Life Is Transformed, New York Times, 15 October 1999, https:/www.nytimes.com/1999/10/15/us/a-tobacco-whistle-blo wer-s-life-is-transformed.html.

Maldives Independent, Rilwan and Yameen's relatives fired for joining protest march, 16 August 2017, https://maldivesindependent.com/society/rilwan-and-ya meens-relatives-fired-for-joining-protest-march-132039.

Melzer, Nils: State Responsibility for the Torture of Julian Assange, Speech at the German Bundestag in Berlin, 27 November 2019 (English translation), 16 December 2019, https://medium.com/@njmelzer/state-responsibility-for-the-tort ure-of-julian-assange-40935ea5d7c3.

Mitchell, Tamsin: Journalists as Human Rights Defenders: International Protection of Journalists in Contexts of Violence and Impunity, in: Shaw, Ibrahim Seaga/Selvarajah, Senthan (eds), Reporting Human Rights, Conflicts, and Peacebuilding (2019), 221ff.

mLIVE: Michigan man made death threat to Trump whistleblower's attorney, feds say, 22 February 2020, https://www.mlive.com/news/saginaw-bay-city/2020/02/m ichigan-man-made-death-threat-to-trump-whistleblowers-attorney-feds-say.html.

Mulé, Nick J.: LGBTQI-identified human rights defenders: courage in the face of adversity at the United Nations, Gender and Development 2018, 89ff.

Near, Janet P./Miceli, Marcia P.: Organizational Dissidence: The Case of WhistleBlowing, Journal of Business Ethics 1985, 1ff.

OSCE: Guidelines on the Protection of Human Rights Defenders (2014).

OSCE: Human Rights Defenders in the OSCE Region: Challenges and Good Practices (2008).

Papandrea, Mary-Rose: Leaker Traitor Whistleblower Spy: National Security Leaks and the First Amendment, Boston University Law Review 2014, $449 \mathrm{ff}$.

Pfeffer, Anshel: Why Breaking the Silence Became the Most Hated Group in Israel, Haaretz, 17 December 2015.

Piccone, Ted: The contribution of the UN's special procedures to national level implementation of human rights norms, The International Journal of Human Rights 2011, $206 \mathrm{ff}$.

Popescu, Ada-Iuliana: A Critical Analysis of Whistleblower Protection in the European Union, Journal of Public Administration, Finance and Law 2015, $135 \mathrm{ff}$. 
Powell, David E: Controlling Dissent in the Soviet Union, Government and Opposition 1972, 85ff.

Rachovitza, Adamantia: The Principle of Systemic Integration in Human Rights Law, International and Comparative Law Quarterly 2017, 557ff.

The Times of India, RTI activists abducted and tortured, 26 December 2013.

UN Commission on Human Rights: Report on the Fortieth Session, UN Doc. E/1984/14(SUPP)-E/CN.4/1984/77, 6 February-16 March 1984.

UN Committee on Economic, Social and Cultural Rights: Human rights defenders and economic, social and cultural rights, UN Doc. E/C.12/2016/2, 29 March 2017.

UN General Assembly: Declaration on the Right and Responsibility of Individuals, Groups and Organs of Society to Promote and Protect Universally Recognized Human Rights and Fundamental Freedoms, UN Doc. A/RES/53/144, 8 March 1999.

UN General Assembly: Final warning: death threats and killings of human rights defenders. Report of the Special Rapporteur on the situation of human rights defenders, Mary Lawlor, UN Doc. A/HRC/46/35, 24 December 2020.

UN General Assembly: Promotion and protection of the right to freedom of opinion and expression. Note by the Secretary-General, UN Doc. A/70/361, 8 September 2015.

UN General Assembly: Promotion of the Declaration on the Right and Responsibility of Individuals, Groups and Organs of Society to Promote and Protect Universally Recognized Human Rights and Fundamental Freedoms: protecting women human rights defenders, UN Doc. A/RES/68/181, 18 December 2013.

UN General Assembly: Situation of human rights defenders. Note by the SecretaryGeneral, UN Doc. A/67/292, 10 August 2012.

UN General Assembly: Situation of human rights defenders. Note by the SecretaryGeneral, UN Doc. A/75/165, 16 July 2020.

UN General Assembly: Situation of human rights defenders. Note by the SecretaryGeneral, UN Doc. A/73/215, 23 July 2018.

UN Human Rights Council: Report of the Special Rapporteur on the situation of human rights defenders. Note by the Secretariat, UN Doc. A/HRC/31/55, 1 February 2016.

UN Economic and Social Council, Promotion and Protection of Human Rights. Human Rights Defenders. Report submitted by the Special Representative of the Secretary-General on human rights defenders, Hina Jilani, UN Doc. E/ CN.4/2006/95, 23 January 2006.

UN OHCHR: Commentary to the Declaration on the Right and Responsibility of Individuals, Groups and Organs of Society to Promote and Protect Universally Recognized Human Rights and Fundamental Freedoms (2011).

UN OHCHR: Declaration on Human Rights Defenders (2020), https:/www.ohchr .org/en/issues/srhrdefenders/pages/declaration.aspx.

UN OHCHR: Human Rights Defenders: Protecting the Right to Defend Human Rights, Fact Sheet No. 29 (2004). 
UN OHCHR: Special Rapporteur on the situation of human rights defenders (2020), https://www.ohchr.org/EN/Issues/SRHRDefenders/Pages/SRHRDefende rsIndex.aspx.

Vaughn, Robert G.: Whistleblowing Law (2015).

Venice Commission: Report on funding of associations, CDL-AD(2019)002, 18 March 2019.

Venice Commission-OSCE/ODIHR: Joint Guidelines on Freedom of Association, CDL-AD(2014)046, 17 December 2014.

Wille, Petter/Spannagel, Janika: The history of the UN Declaration on Human Rights Defenders: its genesis, drafting and adoption, Universal Rights Group Blog, 11 March 2019, https://www.universal-rights.org/blog/the-un-declaration-o n-human-rights-defenders-its-history-and-drafting-process/. 